\title{
United we stand, divided we fall: the early Nietzsche on the struggle for organisation
}

\author{
James S. Pearson (1D) \\ Philosophy, Universiteit Leiden, Leiden, Netherlands
}

\begin{abstract}
According to Nietzsche, both modern individuals and societies are pathologically fragmented. In this paper, I examine how he proposes we combat this affliction in his Untimely Meditations. I argue that he advocates a dual struggle involving both instrumental domination and eradication. On these grounds, I claim the following: 1 . pace a growing number of commentators, we cannot categorise the species of conflict he endorses in the Untimely Meditations as agonistic; and 2. this conflict is better understood as analogous to the species of struggle that Schopenhauer describes in his account of purposive organisation.
\end{abstract}

ARTICLE HISTORY Received 14 May 2017; Accepted 7 May 2018

KEYWORDS Nietzsche; Agon; Schopenhauer; Conflict; Organisation

Donning the mantel of cultural physician, the early Nietzsche diagnoses modern Europeans as suffering from a pathological form of disintegration: 'we see that everything is hostile to everything else and all the noble forces are engaged in a mutually devastating war of annihilation' (WEN, 187; KSA, $7: 30[8], 734){ }^{1}$ What is more, he informs us that this affliction manifests itself at both the psychological level of the individual (i.e., amongst our values and behavioural impulses) and the social level of the community (i.e., between social agents). But what course of treatment does Nietzsche prescribe as an antidote to this ubiquitous state of disorder?

There is at present a tendency to interpret Nietzsche as proposing that we remedy disintegration by transforming antagonistic into agonistic relations. ${ }^{2}$ In other words, rather than seeking to altogether pacify the elements that are at variance with one another, we should endeavour to hold them in a state of tense mutual struggle; yet, ex hypothesi, this should be a species of struggle that leads to the empowerment, as opposed to the detriment, of the whole in question. In this paper, I refute the agonistic interpretive approach by

CONTACT James S. Pearson jamesspearson@gmail.com Philosophy,Universiteit Leiden,Leiden, Netherlands

(c) 2018 The Author(s). Published by Informa UK Limited, trading as Taylor \& Francis Group.

This is an Open Access article distributed under the terms of the Creative Commons Attribution-NonCommercial-NoDerivatives License (http://creativecommons.org/licenses/by-nc-nd/4.0/), which permits non-commercial re-use, distribution, and reproduction in any medium, provided the original work is properly cited, and is not altered, transformed, or built upon in any way. 
demonstrating its profound incompatibility with Nietzsche's conception of organisation in his Untimely Meditations (hereafter UM).

Those propounding this reading take their notion of agonal conflict from Nietzsche's early writings on the ancient Greek agon, particularly his early unpublished essay 'Homer's Contest' (hereafter HC). According to Nietzsche, the ancient Greeks productively channelled their desire for strife and triumph away from murderously destructive struggle (Vernichtungskampf) and into measured contest (Agon, Wettkampf) (HC, 95-6). Such measured competition was omnipresent in ancient Greece - in philosophy, the arts, juridical fora, and, perhaps most obviously, in sporting contests. Following thinkers such as Jacob Burckhardt and Ernst Curtius, Nietzsche famously praised this culture of contest on account of its socially salubrious effects: the combined activity of each citizen striving to improve themselves in an envious effort to outstrip their neighbours issued in an overall flourishing of society. Nietzsche thus affirmatively cites the proem to an edition of Hesiod's Work and Days, which states that such a culture of contest 'drives even the unskilled man to work; and if someone who lacks property sees someone else who is rich, he likewise hurries off to sow and plant and set his house in order' (HC, 97).

For our current purposes, we should remark that Nietzsche's concept of agonal struggle is defined by three necessary criteria:

(1) It is conceptually opposed to destructive struggle (Vernichtungskampf) - in agonal competition, one does not annihilate, or seek to annihilate, one's opponent (HC, 97).

(2) It takes place between parties of approximately equal ability (with respect to the competitive practice in question). Such parity is necessary to elicit the envy and ambition that motivates agonal contest: I am neither envious of those whom I consider to be vastly superior, nor do I entertain any ambitions of outdoing them. It was for this reason that excessively superior individuals were ostracised from ancient Greek agonal societies (HC, 98). ${ }^{4}$

(3) It does not establish instrumental relations such that losers are placed in a relation of servitude to the victors. Dominance is nominal and, congruent with this, the struggle is most commonly conceived by Nietzsche as a struggle for fame (Ruhm, Nachruhm) (HC, 98).

Given the socially strengthening effect that Nietzsche attributes to agonal conflict in $\mathrm{HC}$, and the fact that he frames such struggle as an alternative to destructive conflict, it is remarkable that in UM, where we find his most sustained attempt in the early phase of his oeuvre to overcome the problem of disintegration, there is no mention of agonal contest (i.e. Agon or Wettkampf). So can we justifiably read the early Nietzsche as petitioning us to 
cultivate agonal relations in order to redress the problem of disunity? To be sure, some commentators have analysed the cultural therapies he proposes in UM through the hermeneutic lens of $\mathrm{HC}^{5}$ The critical thesis I defend in this paper, however, is that his prescriptions in UM are patently unagonistic insofar as they contravene the aforementioned criteria of agonal contest.

My positive contention, on the other hand, will be that far more light can be shed on Nietzsche's early struggle for organisation if we analyse it through the interpretive prism of Schopenhauer's thoughts on purposive organisation (Zweckmäßigkeit) in the first volume of The World as Will and Representation (hereafter WWR I). ${ }^{6}$ I take issue with the assumption that Schopenhauer had little influence on Nietzsche's thought during UM. As Cavell matter-of-factly asserts apropos the second meditation: 'Schopenhauer, as everyone notes, is scarcely present in the text'. ${ }^{7}$ Others have also claimed that Nietzsche more generally abandoned Schopenhauer's conception of organisation as of the late 1860 s. $^{8}$ Contrary to this position, I will argue that Nietzsche follows Schopenhauer in viewing organisation as the fruit of a dual struggle for, on the one side, the instrumental domination of that which is deemed serviceable, and, on the other, the eradication of that which is deemed redundant or injurious.

As will become evident, what is at stake in approximating Nietzsche's project to his vision of the agonal Greeks is that one risks unduly softening his prescriptions and neglecting the cogent reasons he proffers for engaging in eradicatory and exploitative modes of contention. It should be observed that in bringing these reasons into relief and exposing a novel conception of flourishing psychological and political unity, this study has a relevance that extends beyond the confines of Nietzsche studies. Not only do the arguments that will be reconstructed below further develop the challenge that Nietzsche presents to contemporary proponents of egalitarian politics, but they also problematize non-exclusionary theories of value pluralism (such as we find in the work of William Connolly, for example). From a Nietzschean perspective, as we will see, both of these theories are guilty of a harmful and misguided breed of idealism.

In the first section, I give a symptomology and etiology of what Nietzsche diagnoses as modern disunity, that is to say, I inquire into how this pathology concretely manifests itself and establish its causes. In the following section, I then expound his proposed remedies. I begin by highlighting how, in WWR, Schopenhauer develops an account of organisation that is markedly unagonistic in kind. In the remaining sections, I illuminate how Nietzsche's proposed therapies paradigmatically replicate the unagonistic structure of Schopenhauer's vision of organisation and its origins. I conclude that we should therefore refrain from employing Nietzsche's notion of the agon as a heuristic device when trying to elucidate the struggle being promoted in UM. 


\section{Diagnosing the crisis of cultural disintegration}

In his opening meditation, 'David Strauss, the Confessor and the Writer' (hereafter DS), Nietzsche criticises the Germans for complacently believing their military victory in the Franco-Prussian war to have been accompanied by a corresponding cultural triumph. He reprimands them for their erroneous conviction 'that struggle and bravery are no longer required' (DS 1, p.4). But to what kind of cultural struggle is Nietzsche rallying his compatriots, whom he pejoratively labels 'cultural philistines' and 'barbarians' (DS 2, p.7)? In trying to address this question, it is instructive to recall Nietzsche's oft-cited definition of barbarism as the 'lack of style or a chaotic jumble of all styles' (DS 1, pp.5-6), and, contrariwise, true culture as the 'unity of artistic style in all the expressions of the life of a people'. In calling Germans barbarians, then, Nietzsche is accusing them of lacking precisely this kind of unity, of being a fragmented 'modern fairground motley' (DS 1, p.6) and 'atomistic chaos' ('Schopenhauer as Educator' [the third meditation, hereafter SE] 4, p.150). We can surmise from this that they must therefore struggle for harmony and against discord. Before we take a closer look at the precise nature of his ideal, though, we should first dissect what Nietzsche means by fragmentation.

On Nietzsche's analysis, one of the root causes of German barbarism is an excess of historical learning (Wissenschaft) and the superficiality of the German approach to education. As a result, Germans have become mere 'walking encyclopaedias' ('On the Uses and Disadvantages of History for Life' [the second meditation, hereafter HL] 4, p.79). Yet amassing knowledge does not strike us as harmful or disintegrative in itself. So why does he deem it a pathology and how does it cause fragmentation? In DS, Nietzsche's chief allegation is that philistinism obstructs authentic agency, especially aesthetic and ethical agency. With respect to the former, he complains that due to the study of sundry languages, literary expression has deteriorated into a 'soulless mosaic of words', with writers clumsily employing an awkward combination of Latin and French styles (DS 11, p.50). Consequently, these authors lack the 'natural basis' and capacity for 'artistic evaluation' needed 'to become even a mediocre and tolerable writer' (DS 11, p.48). Nietzsche therefore scorns this disarray of styles because it leaves potential artists in want of the fixed set of rules and criteria of judgement that they require to guide their artistic practice.

Nietzsche also condemns the German proclivity for accumulating inordinate quantities of knowledge on account of its having thwarted ethical agency. The problem is that one simply cannot implement all of the ethical models that one has ingested from past cultures - namely, on account of their incompatibility. For example, in SE he criticises the toing and froing (Hin und Her) generated in the individual by the conflicting ideals of Christianity and antiquity. The struggle of these value systems 
'engenders a restlessness, a disorder in the modern soul which condemns it to a joyless unfruitfulness' (SE 2, p.133). In presenting the individual with incompatible maxims and models for action, such discordance ultimately paralyses the individual in a manner reminiscent of Buridan's ass.

The second form of harmful disintegration indexed by Nietzsche concerns the chasm he identifies between the inner (i.e., private and intellectual) and outer (i.e., public and practical) aspects of the individual's life. In HL 4 , he recounts how, as a result of her inner havoc, the modern individual has simply abandoned the toilsome task of practically implementing her acquired knowledge. In lieu of doing so, she has simply turned inwards, disregarding the task of taking authentic decisions as to how to intercourse with others and present herself to the outside world (HL 4, p.79). ${ }^{9}$ In their effort to circumvent the problem of practically applying this internal bedlam of ethical and artistic models, modern Germans simply defer to convention and the imitation of others: ' $[\mathrm{N}] \mathrm{o}$ one dares to appear as he is, but masks himself as a cultivated man, as a scholar, as a poet, as a politician' (ibid.). To the extent that they thereby fail to exteriorise their personal inner life, Nietzsche maintains that Germans suffer from a 'weakness of personality' (HL 10, p.116). What is most harmful about the resultant atmosphere of conformism, however, is the way in which it impedes the cultivation of true individuals. Any nascent true individuals are forced to suppress, rather than nurture, their uniqueness out of 'fear of [their] neighbour, who demands conventionality' (SE 1, p.127). This, then, is what Nietzsche is rebuking when he emphatically lambasts 'the antithesis of form and content, of inwardness and convention' ( $\mathrm{HL} 4, \mathrm{p} .82)$.

The third species of fragmentation fostered by philistine culture is more social in kind. The sheer quantity of history ingested by the educated barbarian evokes a destabilising sense 'of the fluidity of all concepts, types and species, of the lack of any cardinal distinction between man and animal'. Nietzsche describes this view of existence as 'true but deadly' (HL 9, p.112). In his eyes, the disorienting experience of existing in a state of pure flux, devoid of higher purpose, breeds a pernicious strain of cynicism towards the world of action ( $\mathrm{HL}$ 5, p.83). Moreover, this attitude issues in a socially divisive form of egoistic immoralism as individuals fall back on the one thing of which they are certain: their own personal life-needs. Needless to say, once the rapacious pursuit of personal gain becomes the social norm, the community 'falls apart [zu Grunde geht] and ceases to be a people [Volk]' (HL 9, pp.112-113).

In UM, Nietzsche's general concern with the pathology of disintegration can therefore be redescribed as a preoccupation with the following triad of specific disorders: 
(a) The anarchic discordance of models guiding agency;

(b) The diremption of our interior, intellectual life from our external comportment, which is consequently governed by convention;

(c) The socially divisive egoism engendered by cynism.

We ought to recall that the evaluative criterion that dominates Nietzsche's thought during this period is the extent to which phenomena aid or obstruct 'an evolving culture and the procreation of genius - which is the goal of all culture' (SE 3, p.358). In their own fashion, each of the aformentioned species of disgregation undercut the social and individual conditions of coordination that are necessary for genius to arise. In contrast to the Hegelian belief that modern Germans have already achieved a 'completion of world-history' (HL 8, p.104) or Hartmann's whiggish conviction that progress is guaranteed by an automatic 'world-process' (Weltprozess) (HL 9, p.107), Nietzsche warns us that the amelioration of our condition is wholly contingent upon our actively fighting for it: '[T] hat ideal condition will not be created by dreaming, it must be fought and struggled for' (HL 9, p.111; emphasis added). We should now inquire into how Nietzsche thinks this fight can best be fought.

\section{Incorporation and eradication: the twofold path to organisation}

As we will presently see, Nietzsche volunteers a number of intertwined solutions to the three forms of disunity delineated in the previous section. One of the key ways that these remedies are related is in their paradigmatic appropriation of Schopenhauer's conception of healthy purposive organisation. Accordingly, we should commence by reconstructing Schopenhauer's position. ${ }^{10}$

Schopenhauer inherits his concern with purposive organisation (Zweckmäßigkeit) from Kant, whose most lucid treatment of the topic is to be found in his Critique of Judgement. Here Kant asks how we can explain the existence of self-organising beings - that is, organisms - in which interdependent parts fit together to harmoniously serve the interests of the whole (what Kant calls inner purposiveness). Kant further asks how we can explain the harmonious holism of nature: how is it that all the world's flora and fauna mutually support one another (as is evidenced by food chains)? And how is it that all of this taken together serves to support rational human culture, which stands at the apex of this grand system (what Kant calls outer purposiveness) $?^{11}$ Since the interdependence of such parts means that they could not have independently pre-existed the wholes to which they belong, Kant argues that we simply cannot conceive of how either outer or inner purposiveness could arise in a purely 
mechanistic universe by force of sheer coincidence. ${ }^{12}$ Kant's response is to suggest that we are forced to make recourse to the concept of teleological causality as a principle of reflective judgement - that is to say, failing a better explanation, we must provisionally think 'as if' such phenomena were the product of intelligent design (2007, §75).

Schopenhauer, by contrast, arrives at a more dogmatic conclusion namely, that purposiveness can only be explained by the fact that the unity of an entity has its ground in the substantial unity of its Platonic Idea, the timeless prototype that determines the development of all individual instantiations of any given natural kind. ${ }^{13}$ Schopenhauer describes these Ideas as being engaged in an unrelenting zero-sum struggle over matter, which they require in order to become fully manifest phenomena; indeed, 'each only has what it has torn away from another' (WWR I, 335).

This 'universal struggle [Kampf]' (WWR I, 172) is then, for Schopenhauer, the turbulent matrix out of which ever higher Ideas enter the world - a process culminating in man, whom he dubs the 'clearest and most perfect objectivation' of the noumenal world-will (WWR I, 178). Yet, in order for the Idea of man to become manifest, Schopenhauer asserts that it must be 'accompanied by the stepwise descent through all animal forms, through the plant kingdom, and down to the inorganic' (ibid.). The reason that man, the ultimate end of nature, needs the existence of this complete, internally conflictual system in order to emerge is that it is precisely this system that provides him with the materials required for his survival.

Whereas outer purposiveness supervenes on the conflictual relations between individual phenomena, Schopenhauer theorises that the inner purposiveness of organisms emerges from the conflict within individual phenomena. Every organism, aside from being constituted by a single idea, supervenes on a hierarchy of Ideas (e.g., organs, cells, molecules, atoms, etc.). Higher Ideas are only able to prevail in the aforementioned universal struggle by pressing lower Ideas into the service of their higher purpose. Schopenhauer illustrates this by adducing the example of the human body's struggle to control its humours, as well as its fight to digest and utilize organic matter.

The appearance of a higher Idea will emerge from this conflict [Streit] and overpower all the less perfect Ideas that were there before, in such a way that it lets their essence continue to exist in a subordinate manner by taking an analogue of them into itself. (WWR I, 169)

This exploitative, instrumentalising struggle to establish hierarchical relations represents the constitutive ground of every phenomenon: 'No victory without a struggle: since the higher Idea or objectivation of the will can 
come forward only by overpowering the lower Ideas, it encounters resistance on their part' (WWR I, 170). Like Kant, Schopenhauer rejects the claim that we can explain organismic unity with reference to exclusively mechanical laws. But diverging from his predecessor, Schopenhauer dogmatically asserts that the only adequate explanation is that Ideas are engaged in this mutual struggle for 'overwhelming assimilation [Assimilation]' (ibid.).

What is more, on Schopenhauer's account, once lower ideas have been coopted, conflict nonetheless persists insofar as subjugated Ideas are constantly struggling to reassert their independence. He thus defines health (Gesundheit) as an organism's ability to subdue this rebellious conflict and keep lower Ideas subordinated to its higher purpose (WWR I, 171). Death often results from the inevitable success of the lower Ideas in their perpetual struggle for independence, which results in the disintegration of the organism. But destructive struggle is also necessitated by the fact that ldeas can only manifest themselves by means of consuming other ideas and thereby commandeering the matter and subordinate Ideas out of which the vanquished were composed. Just as a victor in battle might sack and enslave a defeated city, the victorious Idea disbands the opposed organisation and instrumentalises the Ideas previously organised therein; hence, 'every animal can maintain itself in being only by constantly destroying another' (WWR I, 172; see also 335).

On the basis of this analysis, we can attribute the following defining criteria to Schopenhauer's model of assimilative struggle:

(1) Within it, opposed relata (Ideas) are aimed at subjugating their counterparts into an instrumental hierarchy.

(2) Its telos, instrumental hierarchy, is associated with health.

(3) It is conditioned by destructive struggle - that is, the forced dissolution of existing unities, which enables the seizure of their constituent parts.

(4) It continues within the aforementioned instrumental hierarchies even once these have been established.

In terms of its structure, this struggle of higher versus lower Ideas has remarkably little in common with the agonal contest described in $\mathrm{HC}-$ namely, on account of its being characterised by inequality, instrumentalisation and, despite its measured aim of subjugation, being conditioned by destructive struggle. Let us now examine how this model informs Nietzsche's prescriptions in UM.

\subsection{Plastic power}

Surveying other texts from the period during which Nietzsche was writing UM, we find strong evidence that he was well acquainted with, and even assented to, Schopenhauer's description of the world as a universal struggle 
for purposive organisation. ${ }^{14}$ Reinforcing the idea that Nietzsche avowed his predecessor's conflict-based conception of organisation, we also find a significant parallelism between this conception and the struggle for unity that Nietzsche promotes in $\mathrm{HL}$.

Despite Nietzsche's critique of over-education, and specifically the overaccumulation of historical knowledge, it should be underscored that he nonetheless posits such knowledge as a necessary condition of health. As he emphatically remarks: '[T]he unhistorical and the historical are necessary in equal measure for the health of an individual, of a people and of a culture' (HL 1, p.63). But how can historical knowledge redress the problematic disintegration to which its excess gave rise in the first place?

Nietzsche tells us that man is simply unable to survive without distorting and exploiting the past in accordance with his needs. Reverberating with Schopenhauer's account of assimilation, he describes this process of pressing history into the service of one's life-needs as one of incorporation (Einverleibung):

The stronger the innermost roots of a man's nature, the more readily will he be able to assimilate and appropriate the things of the past; and the most powerful and tremendous nature would be characterized by the fact that it would know no boundary at all at which the historical sense began to overwhelm it; it would draw to itself and incorporate into itself all the past, its own and that most foreign to it, and as it were transform it into blood. (HL 1, pp.62-3)

The ability to exploit history in order 'to transform and incorporate into oneself what is past and foreign, to heal wounds, to replace what has been lost, to recreate broken moulds' is what Nietzsche refers to as 'the plastic power [Kraft] of a man, a people, a culture' (HL 1, p.62). He takes the pre-Socratic Greeks to have exemplified this ability: they drew together their knowledge of foreign cultures and applied it to their real needs (ächte Bedürfnisse). ${ }^{15}$ Their awareness of their authentic needs endowed the Greeks with a standard according to which the tumult of foreign influences could be regimented: 'The Greeks gradually learned to organize the chaos by following the Delphic teaching and thinking back to themselves, that is, to their real needs, and letting their pseudo-needs die out' (HL 10, p.122).

Nietzsche recommends that exemplars from past or foreign cultures - that is, models and standards for aesthetic and ethical agency - should only be maintained and taught to subsequent generations if they can be implemented as expedients in the face of current obstacles. Accordingly, that which a vibrant individual or culture 'cannot subdue it knows how to forget' (HL 1, p.63). Forgetfulness, which represents the counter-dynamic of incorporation, is what Nietzsche dubs the 'unhistorical' mode of existence (ibid.). At a stroke, this strategy promises to resolve both (a) and (b). First, by implementing utilisable knowledge, and forgetting redundant knowledge, a combination of 
influences is fashioned that is tailored to one's true aesthetic and ethical needs. Second, in applying one's knowledge, one reconnects one's inner life (of knowledge and belief) with one's external existence (in praxis).

It should be clear from this analysis that the conflictual relation Nietzsche encourages us to take towards foreign and past cultural influences cannot justifiably be described as agonal. The primary reason for this is that the struggle is largely depicted as being motivated by the goal of instrumentalisation. As Vanessa Lemm $(2013,6)$ has tellingly put it, according to Nietzsche's ideal, 'the human being appropriates, dominates and rules over the past'.

Herman Siemens has observed that the dynamic of incorporation delineated in HL bears a striking resemblance to the process of 'transposition' (Übertragung) that is depicted in $\mathrm{HC}$ - that is, the process by which the Greeks harnessed their ordinarily destructive and bellicose drives for struggle and victory by channelling them into, and granting them release through, culturally productive agonal contest. On these grounds, Siemens (2001a, 101) holds the incorporative struggle described in $\mathrm{HL}$ to be an agonal mode of conflict:

The key to Nietzsche's thought here is a notion of productive and inclusive conflict that he derives from the signature institution of pre-Socratic culture: the contest or agon (Wettkampf). It is through a transformative assimilation or Übertragung - of natural, destructive drives that the agon was born.

However, the fact that the agon emerges out of a form of assimilative struggle is not enough to justify labelling that originary struggle agonal (indeed, to claim otherwise would be to commit a genetic fallacy). Nor is the fact that the resultant organisation is productive a sufficient condition for categorising such assimilative struggle as agonal in kind. To be sure, the struggle to incorporate implementable phenomena is, like the agon, a non-destructive and culturally productive mode of conflict; yet as was determined in our introduction, the agon is not motivated by the desire to instrumentally command one's opponent, as is the case with assimilative struggle. Agonal and assimilative conflict are sui generis modes of struggle that we should take care not to conflate.

Another way that $\mathrm{HL}$ resists agonistic readings is in its persistent valorisation of unmeasured conflict. As we have just witnessed, Nietzsche exhorts us to forget expendable knowledge and let our 'pseudo-needs' die out, thereby ridding ourselves of their harmful influence. The organisational struggle that Nietzsche propounds is therefore defined by both the struggle to include useful knowledge within the horizon of one's true needs and the fight to conclusively exclude redundant knowledge and needs from that same horizon. Furthermore, this latter struggle is not one that aims to maintain a conflictual relation with that which has been excluded; rather, complete 
annihilation is its telos - any excluded or forgotten datum of knowledge 'no longer exists, the horizon is rounded and closed' (HL 1, p.63; emphasis added). It should be added that while this process of elimination recalls the exclusive practice of ostracism described in $\mathrm{HC}$, this does not warrant our calling it agonal. First, to my mind, the eliminatory species of struggle denoted by ostracism should not itself be understood as agonal; rather ostracism stands as a non-agonal safeguard of agonal contest and should not be confounded with the type of conflict that it ensures. Second, in HC, ostracism functions as a fall-back measure that is only called upon in the event that other sources of moderation fail (e.g. the mutual limitation that approximately equal contestants impose upon one another), and such failure is by no means inevitable. ${ }^{16}$ As such, ostracism is not a necessary component of agonal culture in the same way that eliminatory stuggle is with respect to the dynamic of organisational conflict.

At the end of $\mathrm{HL}$, Nietzsche reiterates this affirmation of unmeasured struggle in petitioning the 'youth', 'that first generation of fighters and dragon-slayers', to execute the urgent task set forth in the body of the essay. In dubbing them 'dragon-slayers' and defending their right to 'coarseness and immoderation [Unmässigkeit]' (HL 10, p.121), he makes it quite transparent that he is campaigning for anything but a measured, agonal mode of conflict. This is a struggle to destroy (zerstören) the beliefs that block the project of cultural renewal, principally by provoking 'mockery and hatred' towards them (ibid.) - that is, through a process of devaluation or radical critique. What distinguishes the forms of unmeasured conflict that Nietzsche advocates from those that he so often rebukes as culturally injurious - for example, the struggle-to-the-death (Vernichtungskampf) described in $\mathrm{HC}$ - is that they promote life and culture by enabling creativity, agency and individuality. Nietzsche states that the great productive spirit only aims to condemn (verurtheilen) 'what to him, as a living being and one productive of life, is destructive and degrading' (HL 4, p.82).

We can therefore read Nietzsche's promotion of organisational struggle as sharing three key structural features with Schopenhauer's notion of assimilative conflict:

(1) It is aimed at subjugation (of the various data of knowledge to a person's or culture's true life-needs).

(2) Its telos, instrumental hierarchy, is associated with health.

(3) It is conditioned by destructive struggle (the omission of redundant knowledge, the radical critique of counterproductive conventions, and the eradication of pseudo-needs).

One notable difference, however, is that whereas Schopenhauer merely describes assimilative conflict as a naturally occurring process, Nietzsche's 
depiction of such conflict has a strong normative bent. For Nietzsche, healthy organisation is contingent on our consciously struggling for it, and he strives to persuade us that we should engage in just such an endeavour.

We might be tempted to infer that the absence of the fourth criterion of assimilative conflict - that such conflict continues within the instrumental hierarchies that it establishes - is indicative of further divergence; yet, if we now turn to the question of self-knowledge as it is worked out in the latter two meditations, we will find that this criterion is in fact satisfied by Nietzsche's broader synthetic project.

\subsection{Knowing thyself}

Self-knowledge represents a sine qua non of the organisational struggle we discovered in $\mathrm{HL}$ : one must know one's true needs in order to synthesise one's historical influences. Such knowledge provides the metric by which one is able to separate the wheat (which should be incorporated) from the chaff (which should be jettisoned) - hence Nietzsche's emphasis on the 'Delphic teaching', that is to say, the maxim: 'know thyself' (HL 10, pp.122-123). In a manner that is germane to our current inquiry, self-knowledge is similarly fundamental within Schopenhauer's account of subjective organisation. Indeed, the conception of self-organisation that Nietzsche develops in the latter two meditations, though especially in $\mathrm{SE}$, is one that in many ways mirrors Schopenhauer's treatment of the issue in WWR.

Each person, says Schopenhauer, possesses their own distinctive character, their unique 'complete personality' (WWR I, 156). Again echoing Kant, Schopenhauer initially informs us that an individual's character, or what he also calls their 'individual will' (WWR I, 318), has two sides: one that appears to us (our empirical character) and one that remains imperceptible (our intelligible character). Like all objects within the Kantian Weltanschauung, our character is undetermined to the extent that it exists outside of space and time (qua intelligible character) as a thing in itself, exempt from the laws of causality. However, our character appears as our empirical character when we make decisions and act in the spatio-temporal world of representation. Nonetheless, it is vital to observe how, for Schopenhauer, each individual's character is in essence fixed. Just like each natural kind, every individual's character is defined by its own unchangeable Platonic Idea. A person's character is accordingly determined at birth (WWR I, 250), and, when presented with a given conflict of motives and a given degree of knowledge about how best to pursue those motives, that person will therefore only ever resolve upon one particular path. Their behaviour is, according to Schopenhauer, determined with iron necessity.

Schopenhauer also identifies a third type of character: acquired character. Man finds in himself, says Schopenhauer, 'the tendencies to all the various 
human aspirations and abilities'; yet, if we are to profitably follow a directed line in life instead of running in a 'zigzag all over the place without getting anything done', some impulses 'must be entirely repressed'. In order to achieve this, 'a human being must also know what he is willing, and know what he can do' (WWR I, 330). He claims that through successive acts we are able to glean a progressively more comprehensive picture of our unique empirical character. Through this knowledge of our empirical character (particularly of our idiosyncratic strengths and weaknesses) we learn which of these impulses must be suppressed in order to follow the life path most suited to our aptitudes.

Nietzsche is openly sceptical regarding the ideal of acquired character that we find in Schopenhauer. Indeed, he opens SE by casting doubt on the very possibility of self-knowledge. Man, he maintains, 'is a thing dark and veiled' who can never say to himself 'this is really you, this is no longer outer shell' (SE 1, p.129). How could we ever be certain that we have obtained insight into our true needs and capacities and not those that merely appear so (viz., our pseudo-needs)? What sense does it make to talk of a core, essential self if it can never be assuredly intuited? Further betraying a desire to distance himself from essentialist conceptions of the self, Nietzsche asserts that, although each of us is a 'Unicum', we are not unified in any substantial sense; rather, echoing Hume's bundle theory of the self, he theorises that we are each 'a so strangely variegated [buntes] multiplicity [Mancherlei] gathered into a unity [Einerlei]' (SE 1, p.127; amended translation).

Yet this should not cause us to omit the strong undercurrent of essentialism running through UM. Throughout SE and 'Richard Wagner in Bayreath' (the fourth and final medition, hereafter WB), we bear witness to Nietzsche referring to the self in strikingly essentialist terms. He speaks of the 'core [Kern] of [one's] essence [Wesens]' (SE 3, p.143; amended translation) and even simply of a person's 'true essence' (wahres Wesen) (SE 1, p.129; amended translation). He further acclaims the way in which Schopenhauer was governed (waltet) by his 'Platonic Idea [/dee]' (SE 5, p.156; amended translation). Finally, he states that our true educators should help us acknowledge a self that sounds remarkably essentialist in kind: they should 'reveal to you that the true, original meaning and basic stuff of your nature is something completely incapable of being educated or formed [Unerziehbares und Unbildbares] [....' (SE 1, p.129). ${ }^{17}$

What is more, despite his reservations regarding the possibility of selfknowledge, Nietzsche nonetheless follows Schopenhauer in regarding knowledge of our authentic self as a condition of self-organisation. This is most clearly evident in the following passage: 
[W] hat have you truly loved up to now, what has drawn your soul aloft, what has mastered it and at the same time blessed it? Set up these revered objects before you and perhaps their nature and their sequence will give you a law, the fundamental law of your own true self: Compare these objects one with another, see how one completes, expands, surpasses, transfigures another, how they constitute a stepladder upon which you have clambered up to yourself as you are now [...]. (SE 1, p.129)

Nietzsche's hypothesis is that recollecting and comparing our highest joys reveals an inner law that describes the ideal trajectory of our selfdevelopment, and that this endows us with a conception of our higher self towards which we can aim. Note that, in contrast to Schopenhauer's conception of empirical character, this fixed inner law is one that directs a continual process of development - it never describes us as we are. We might think of it as being analogous to the algebraic formula that describes the pattern in an existing series. Such a formula, while lacking any determinate content of its own, nonetheless allows us to deduce how the series should continue for higher values.

The discovery of this inner trajectory is of interest to Nietzsche because, recalling $\mathrm{HL}$, such self-knowledge forms the basis for organising the self into a 'harmonious whole' (SE 2, p.131). It enables one to become someone

in whom everything, knowledge, desire, love, hate, strives towards a central point, a root force, and where through the compelling and commanding supremacy [die zwingende und herrschende Uebergewalt] of this living centre, a harmonious system is constructed here and there, above and below. (SE 2, p.131; amended translation)

This idea is also apparent in Nietzsche's description of Wagner in WB, whom he praises for the 'severity and uniformity of purpose he imposed upon his will' (WB 9, p.244):

[F]rom the moment when his ruling passion became aware of itself and took his whole nature in its charge [...] there was an end to fumbling, straying, to the proliferation of secondary shoots, and within the most convoluted courses and often daring trajectories assumed by his artistic plans there rules a single inner law [Gesetzlichkeit], a will, by which they can be explained [...]. (WB 2, p.200)

Once the ideal trajectory of our self has been deduced, or becomes 'aware of itself', it functions as what Nietzsche describes as a 'root' or 'cardinal force', that is, a 'middle-point' under and around which all our other capacities can be organised. ${ }^{18}$ In accordance with Schopenhauer's account of acquired character, ascertaining our calling in life is said to give us the fundamental criterion we need in order to synthesise our 'knowledge, desire, love, hate' into a stable and coherent structure. This holism is attained by determining how every other subjective force can serve this authentic calling and then ordering these forces accordingly. ${ }^{19}$ We should 
also call attention to the fact that Nietzsche not only construes this central point as the cornerstone or fulcrum of self-organisation but, additionally, as the organising force itself.

There is unfortunately not space to satisfyingly explore Nietzsche's conception of the true self in UM, which, as I have indicated, is envisioned in a number of different ways (viz., a quasi-Schopenhauerian Idea, a quasiHumean bundle, and a quasi-Aristotelian developmental law). Nietzsche undoubtedly vacillates over this issue, as he does vis-à-vis the possibility of self-knowledge. Determining his ambiguous relation to Schopenhauer's essentialism in UM, however, is not necessary with respect to our principal objective: illuminating the unagonistic impetus of the text. It suffices to remark that Nietzsche consistently posits the existence of a deeper part of the self that he believes ought to govern the remainder of the self in a stably centralised manner. This is problematic for agonistic readings of UM for two reasons. Firstly, because the struggle for self-governance that Nietzsche is promoting is unambiguously directed at the instrumentalisation of the serviceable forces of the self. Secondly, the notion of a 'living centre' enduringly reigning over the hierarchy of the self is profoundly at odds with the fluid pluralism of approximately equal powers that characterises Nietzsche's agonism. In HC, his idealised agonal community is defined by decentred constellations of mutually limiting forces - what Nietzsche calls the 'contest of powers' [Wettspiel der Kräfte]) - and where any hegemon is forcibly removed by means of ostracism ( $\mathrm{HC}, 98)$. Note that these points, aside from controverting the agonistic approach, also positively vindicate the idea that we should read UM in terms of the exploitative struggle for assimilation described by Schopenhauer.

But there are yet further reasons that we might favour this Schopenhauerian interpretive framework. For Nietzsche, the struggle for purposive organisation does not only involve the measured, inclusive process of coordinating our inclinations into a functional hierarchy; rather, this process is necessarily accompanied by an unmeasured struggle of eradication, for 'the removal of all the weeds, rubble and vermin that want to attack the tender buds' of a burgeoning culture (SE 1, p.130). Nietzsche's sights are set on the dross conventions that hinder the fruition of genius. Indeed, he argues that Schopenhauer only assailed 'those aspects of his age that prevent[ed] him from being great', with the specific aim of recovering 'the health and purity native to him' (SE 3, pp.145-6). Once again, note that what are being destroyed (zerstört) are, according to Nietzsche, doxai, and how they are being destroyed is by means of radical critique, or denial (Verneinung) (SE 4, p.151).

Like Schopenhauer, Nietzsche sees the discovery of our inner self as a source of purposiveness and increased efficacy; yet, whereas Schopenhauer merely emphasises the way this revelation provides the basis necessary for suppressing (unterdrücken) diverting impulses, Nietzsche accents how it can 
act as an Archimedean point around which our forces can be synthesised and stimulated. The ideal educator, says Nietzsche, should not just engender the harmonious ordering of their pupil around a dominant 'central root', but they should also 'foster and nourish all available forces' (SE 2, p.130; amended translation). Only wholly recalcitrant impulses should be eradicated on Nietzsche's account. As such, the ordering Nietzsche seeks is not one that simply forces our inclinations into passive submission to our core selves; this order is rather the very means by which subaltern forces can be fomented and held in ever greater degrees of tension with one another. ${ }^{20}$ We should therefore not construe this dominating centre as having an exclusively suppressant effect on the forces harmonised beneath it. Rather, it maximises their mutual conflict, while constantly struggling to keep this contention within beneficial limits. With this, we can affirm that the struggle proposed by Nietzsche as a solution to individual disintegration fulfils the final criterion of Schopenhauer's model of assimilative struggle - namely, that such struggle continues within the instrumental hierarchies that it establishes (4).

\subsection{Common purpose}

We have so far been concerned with mapping out Nietzsche's prescribed remedies for individual disintegration. What remains to be seen, however, is how he proposes we counteract disintegration at the level of the collective. To be sure, Nietzsche is at pains to show us that acknowledging our need to strive for our higher (integrated) self imposes duties upon us that

are not the duties of a solitary; on the contrary, they set one in the midst of a mighty community held together, not by external forms and regulations, but by a fundamental idea [emphasis added]. It is the fundamental idea of culture, insofar as it sets for each one of us but one task: to promote the production of the philosopher, the artist and the saint within us and without us and thereby to work at the perfecting of nature. (SE 5, p.160)

For Nietzsche, collectively acknowledging our duty to engender genius therefore functions as the primary foundation for social organisation. What we now need to determine, however, is whether we can categorise this collective struggle - that is, the 'struggle for culture' (Kampf für die Kultur) (SE 6, p.163; amended translation) as agonistic.

In trying to elucidate the kind of struggle Nietzsche has in mind here, we should begin by underlining the deep equivocation in how he conceives of genius, which constitutes the goal of his cultural program. On the one hand, he adopts the Kantian understanding of genius as a 'talent' (Talent, Naturgabe) or 'the innate mental aptitude (ingenium) through which nature gives the rule to art' (Kant 2007, 136). Needless to say, on this conception, the talent characteristic of 
genius is only enjoyed by a minority of innately gifted individuals. This is what I will call elite genius. Aristocratic readers such as Rawls have argued that Nietzsche exclusively promotes this form of genius in SE. Rawls $(1971,325)$ reads SE as stating that it is the sole principle of a teleological theory directing society to arrange institutions and to define the duties and obligations of individuals so as to maximise the achievement of human excellence in art, science, and culture. ${ }^{21}$ On this interpretation of Nietzsche's perfectionism, the majority of individuals must sacrifice their personal self-development for the sake of cultivating a minority of elite geniuses. And certainly, there are passages that unmistakably support this interpretation - for instance, where Nietzsche asks the reader the following: ' $[\mathrm{H}]$ ow can your life, the individual life, receive the highest value, the deepest significance? [...] Certainly only by your living for the good of the rarest and most valuable exemplars, and not for the good of the majority' (SE 6, p.162).

On the other hand, alongside this, following Romantics such as Byron and Emerson, Nietzsche also employs a more global conception of genius qua the capacity for originality and authenticity, which inheres in everyone, without exception. Thus, Emerson $(1870,188)$ proclaims to all of his readers that 'Genius is the power to labor better [...]. Deserve thy genius; exalt it.' This is what I will refer to as the global conception of genius. Cavell, and following in his wake, James Conant, both reject Rawls' reading by contending that Nietzsche prioritises the cultivation of this type of genius: "[T] he "something higher and more human" in question is not [...] that of someone else, but a further or eventual position of the self now dissatisfied with itself' (Cavell 1990; 52; see also Conant 2001; 203). And to be sure, we can also adduce passages from SE that seem to substantiate this reading - for example, where Nietzsche states that 'culture is the child of each individual's self-knowledge and dissatisfaction with himself' (SE 6, p.162; emphasis added).

What, then, is the one goal that is meant to be binding us together, and for which we are meant to be striving - the cultivation of my global genius or the cultivation of others' elite genius? In fact, as we will now see, Nietzsche views these as mutually complementary undertakings the cultivation of genius 'outside us' and 'within us' represent 'one task' (SE 5, p.160).

In the final sections of SE, Nietzsche proffers two arguments for why we ought to endeavour to cultivate the elite genius of others. The first argument requires little more than the realisation that we must each strive to become elite geniuses ourselves. According to this line of reasoning, he suggests that it is in our own personal interest, as aspiring elite geniuses, to create a social environment that fosters this type of genius in others. First, because our personal struggle to achieve elite genius demands the aid of other elite geniuses. We need exemplars to illuminate, and spur us towards, higher goals - 'we have to be lifted up' (SE 5, p.159). Second, in fashioning an 
environment in which elite geniuses are able to achieve their highest potential, Nietzsche thinks that we simultaneously create an environment in which we can independently strive to attain our highest potential. In struggling against the social forces that prevent elite geniuses such as Schopenhauer from emerging, we also 'unwearyingly combat [ankämpfen] that which would deprive us of the supreme fulfilment of our existence by preventing us from becoming such Schopenhauerian men ourselves' (SE 5, p.160). This implies a fairly straightforward compatibility of egoistic and collective goals.

But what about those individuals who know themselves to be wholly incapable of attaining the heights of elite genius - 'second and third rate talents' as Nietzsche calls them (SE 6, p.176)? How can he persuade such individuals, who might quite reasonably take their egoistic interests to be incompatible with those of the elite genius, to devote themselves to this higher, cultural goal?

In order to convince such middling types, Nietzsche declares that generating elite genius represents the highest end of nature, and thus it is only in collectively pursuing this end that the mediocre can realise their highest calling. Otherwise put: it is only in contributing to the procreation of elite genius that the majority can maximise their own global genius. Nietzsche's argument hinges on the supposition that '[n]ature needs knowledge' in order to attain redemption (Erlösung) (SE 5, pp.158-9), and it can only attain this by means of the elite genius, who therefore constitutes nature's highest goal. Although elucidating this rather esoteric claim, which is based on an admixture of Hegel, Kant and Schopenhauer, would undoubtedly be enlightening, doing so would cause us to digress from our main line of inquiry. What is worth mentioning, however, is that Nietzsche follows Schopenhauer in viewing nature as vainly pressing towards its goals. In WWR, this conception of nature is perhaps most conspicuously presented in Schopenhauer's vision of the artistic genius:

[A]ctual objects are almost always very deficient exemplars of the Idea presented in them: hence the genius needs imagination [Phantasie] in order to see in things not what nature actually created, but rather what it was trying unsuccessfully to create, a failure due to that struggle between its forms [...]. (WWR I, 210; emphasis added)

In an analogous manner, Nietzsche considers nature to be incapable of achieving its goal of producing ideal humans (i.e. elite geniuses) unaided: we see 'nature pressing towards man and again and again failing to achieve him' (SE 6, p.163). Consequently, he deems it necessary 'to replace that "obscure impulse" with a conscious willing' (SE 6, p.164). This is what he describes as the 'metaphysical significance [Bedeutung] of culture' (SE 6, p.175). Culture's true raison $d^{\prime} \hat{e}$ tre is to expedite nature's otherwise futile efforts at realising genius: '[E] 
verything calls to us: come, assist, complete, bring together what belongs together, we have an immeasurable longing to become whole' (SE 6, p.163).

This argument can therefore be summarised as follows: given that nature's highest goal is the production of elite genius, it is our goal to assist nature in achieving this, even if we are without hope of becoming elite geniuses ourselves. Contrary to Cavell's interpretation, Nietzsche demands the sacrifice of our egoistic goals for the sake of elite geniuses - that is, 'on behalf of another individual [Einzelner]' (SE 6, p.162; emphasis added). ${ }^{22}$ Crucially, this gives us further cause to reject agonistic readings insofar as the social order that Nietzsche is striving to realise with such arguments is one unquestionably characterised by entrenched inequality and instrumental relations. Yet, we must take care not to misinterpret the nature of this instrumentalisation. Contrary to Rawls's reading, it is not conceived as an oppressive social arrangement. Instead, Nietzsche stresses that lesser individuals stand to gain by acquiescing to their metaphysical duty, since it is only in so doing that their lives come to 'possess significance and a goal' (SE 6, p.176). ${ }^{23}$ It is only by voluntarily serving elite genius that we realise nature's highest purpose and, thereby, our own highest capacities. In striving to fulfil this external end, we therefore concurrently work towards maximising our own inner, global genius. ${ }^{24}$

It should by now be apparent that neither the reading of Rawls nor that of Cavell stand up to scrutiny - the entire either/or approach is misguided. Both err in assuming that Nietzsche is operating with one or the other of the aforementioned definitions of genius. In actuality, he invokes both conceptions, and, furthermore, argues that when taken as cultural goals, they are even mutually complementary.

In formulating these collective ends, Nietzsche proves himself to be fulfilling what he designates as the ideal cohesive function of the philosopher qua 'physician of culture': to 'bind everyone through a common goal [Ziel]' (WEN, 187; KSA 7:30[8], 734; see also KSA 7:30[7], 732). Nonetheless, it should be restated that Nietzsche principally strives to establish this cohesion by cajoling large swathes of society into an enduring position of subservience. ${ }^{25}$ This is pertinent because it is on these grounds that we can rebut agonistic conceptions of Nietzsche's struggle for culture in SE.

As we turn to some of Nietzsche's more concrete recommendations as to how we might achieve cultural renewal, we unearth yet more obstacles to the agonistic approach, and, simultaneously, further support for our Schopenhauerian reading. First, Nietzsche quite minimally calls for the creation of a sequestered social space for cultivating elite geniuses, one shielded from all demands extraneous to this goal, be they the needs of the economically or politically powerful, or even the elite genius's own survival needs (she should have 'no necessity for bread-winning') (SE 8, p.182). Nietzsche commends the 
'small band' who view cultural institutions as a bulwark (Schutzwehr) shielding elite geniuses from the vulgar utilitarian demands of society (SE 6, p.176). ${ }^{26}$ With respect to philosophical genius, one way that Nietzsche envisions this being realised is through the complete purgation of philosophy from the university system, which, he tells us, has rendered the discipline ridiculous by allowing it to be subordinated to the ends of the state. It is therefore a 'demand of culture that philosophy should be deprived of any kind of official or academic recognition [...]. Let the philosophers grow untended' (SE 8, p.190). In this way, Nietzsche incites his readers to a quite unagonistic fight for the complete abolition of academic philosophy.

Nietzsche's struggle for culture is indissociable from a 'hostility towards those influences, habits, laws, institutions in which he fails to recognize his goal [Ziel]: the production of the genius' (SE 6, p.163; amended translation). Yet, as we have just seen, this hostility is definitely not wholly measured in kind. Indeed, Nietzsche applauds Wagner for acknowledging the fact that 'the genius must not fear to enter into the most hostile relationship [feindseligsten Widerspruch] with the existing forms and order' (SE 3, p.137). This resistance is strikingly described as superlatively hostile towards cultural orders that stymie the generation of genius. Given this endorsement of immoderate hostility, we can once again see how misrepresentative it is to refer to Nietzsche's proposed 'struggle for culture' as an agon of individuals against society. ${ }^{27}$

This initial act of purgation must then be followed, Nietzsche instructs us, by a process of 'continual purification [Läuterung]', whereby any encroachment of extraneous demands into the cultural refuge of the elite genius is promptly thwarted (SE 6, p.176). Even once the necessary social hierarchy has been erected, then, the battle is not over; indeed, it is never over. The struggle for culture is a relentless endeavour to maintain this ideal hierarchy by combatting social structures that are inimical to the elite genius. ${ }^{28}$

With this affirmation of perpetual strife as a necessary condition of purposive social organisation we can now soundly conclude that Nietzsche's struggle for culture, in addition to being incompatible with his notion of agonal conflict, positively instantiates the key structural features of Schopenhauer's model of assimilative struggle. Analogous with Schopenhauer's model, we can therefore state the following about the kind of cultural contention that Nietzsche advocates in UM: 1 . it is directed towards instrumental hierarchy (with the majority serving the needs of elite genius); 2 . the hierarchy for which it strives is associated with (cultural) health; 3 . it is inextricable from unmeasured conflict (towards social conventions that hamper elite genius); and 4. the struggle persists within the resultant hierarchies (as a struggle to maintain this hierarchy through 'continual purification'). 


\section{Conclusion}

We now have a comprehensive picture of Nietzsche's remedies for the three pathological forms of disintegration that we enumerated in Section 1. Against the self-fragmentation that hindered agency (a), we found him recommending an unagonistic struggle to instrumentalise the utilisable knowledge, habits and values that we have acquired from other cultures. By subordinating these to our true life-needs, we form them into an integrated whole which is able to facilitate agency. On the other hand, he enjoins us to eliminate redundant cultural influences, that is to say, those that do not serve our life-needs. It is then through this very same dual struggle that he thinks we can resolve the pathological diremption of our inner and outer life (b). By forging the myriad of habits, beliefs and values that an excess of learning has encumbered us with into a coherent unity dominated by our life-needs, these internal psychological influences on our agency thereby become externally applicable in our quotidian practical life. Finally, with respect to the social division Nietzsche associates with cynical egoism (c), he recommends collective subscription to the metaphysically grounded goal of cultivating elite genius.

Although this assimilative struggle can be considered measured insofar as it aims to preserve that which is deemed useful, we have also seen Nietzsche persistently emphasising the need for unmeasured conflict, that is to say, the ferociously hostile struggle against those habits, opinions, traditions and institutions that impede the task of self- and socialunification. Measured incorporation and unmeasured eradication are two dimensions of a single dynamic that has coordination as its end - hence my treating both processes under the rubric of organisational struggle. In misconstruing Nietzsche's prescriptions in UM as agonistic in kind, previous commentators have tended to overlook the value that he identifies in hierarchical organisation, instrumentalisation and eradication. Given the risk of such oversight, we should therefore exercise caution before analysing Nietzsche's wider philosophy through the interpretive prism of HC.

The secondary objective of this study was to illuminate the significant structuring influence of Schopenhauer on Nietzsche's thought in UM. It should now be beyond reasonable doubt that, in UM at any rate, Nietzsche paradigmatically deploys a Schopenhauerian notion of healthy, purposive organisation. Notwithstanding, we should not mistake this structuring influence for a wholesale avowal of Schopenhauer's position. Indeed, we have seen Nietzsche significantly modifying various aspects of Schopenhauer's account of purposive organisation. For example, he gives Schopenhauer's purely descriptive treatment of organisation a strongly normative dimension, urging us to conceive of healthy unity as an accomplishment contingent on our conscious efforts. Moreover, we 
found Nietzsche repeatedly striving to de-essentialise Schopenhauer's notion of character. These observations, however, should not cause us to forget the numerous moments we uncovered where Nietzsche refers to both the self and nature in markedly Schopenhauerian, metaphysical terms - terms that he unequivocally disowns during the middle and late phases of his philosophy. To this extent, UM should be read as a transitional work in which Nietzsche can be seen vacillating over his Schopenhauerian heritage. The ironic consequence of this is that UM, a text that places such a high value on concord, exhibits a remarkable degree of discord in its stance towards Schopenhauer's philosophy.

\section{Notes}

1. Throughout this paper, I will be using the following abbreviations for Nietzsche's writings:

DS:'David Strauss, the Confessor and the Writer' (Nietzsche 1997a).

EH:Ecce Homo (Nietzsche 2007).

HC:'Homer's Contest' (Nietzsche 2006).

HL:'On the Uses and Disadvantages of History for Life' (Nietzsche 1997b).

KSA:Kritische Studienausgabe (Nietzsche 1988). References refer to volume number, notebook, fragment and page number (in that order). Thus, KSA, 7:30[8], 734 refers to Volume 7, Notebook 30, Fragment 8, page 734.

PTG:Philosophy in the Tragic Age of the Greeks (Nietzsche 1998).

SE:'Schopenhauer as Educator' (1997d).

UM:Untimely Meditations (1997e).

WB:'Richard Wagner in Bayreuth' (Nietzsche 1997c).

WEN: Writings from the Early Notebooks (Nietzsche 2009).

2. For commentators who suggest this in the context of Nietzsche's social philosophy, see Acampora (2006). In her treatment of the agon, Acampora emphasises how, for Nietzsche, 'competitive relations serve as an organising force of culture by bringing together diverse elements [and] coordinating heterogeneous interests' (327). Tuncel (2013) has defended a similar position (see ch.6). We can also situate agonistic democrat interpretations of Nietzsche in this group - e.g., the work of Lawrence Hatab, William Connolly, David Owen and Mark Warren, all of whom read Nietzsche as proposing agonism as a socially cohesive principle.

For commentators who describe Nietzsche's vision of the healthy self as one that is agonally organised, see e.g., Gemes (2009, 56 [fn.21] and 49-52). Gemes repeatedly refers to Nietzsche's normative vision of an 'agonal struggle between drives'. See also Richardson $(1996,30)$.

3. For a comprehensive analysis of how this measure is concretely realised, see Pearson (2018a).

4. We should bear in mind, though, that the psychological conceptions of healthy agonal struggle that Richardson (1996) and Gemes (2009) respectively develop out of Nietzsche's thought involve a master drive's non-destructive struggle for the domination of weaker drives. While I would argue that this constitutes a misuse of Nietzsche's notion of agon, it nonetheless shows that there are models of Nietzschean agonism that do not presuppose that such contest takes place inter pares. This said, insofar as this conflict is still figured by both Gemes and Richardson 
as non-eliminative in nature, this paper will still be rejecting their interpretations of Nietzsche's ideal. See Gemes (2009) and Richardson (1996, 33). Similarly, Tuncel (2013) also puts forward a model of agonal contest at a social level that involves some minimal notion of hierarchy and servitude: 'the weak have to serve the strong; the losing contestants must accept their defeat and look up to the strong' (173). I would again contend that this conception of Nietzsche's notion of 'agonism' takes us too far from the letter of his own usage, which, on the whole, does not permit of instrumental hierarchy.

5. For example, Acampora $(2013,39)$ has alleged that $\mathrm{HL}$ 'draws on and extends the agonistic model he earlier describes [in HC].' See Acampora (2013, 36-42). See also Siemens (2001a), 80-106. Vanessa Lemm $(2007,14)$ reads SE as endorsing 'a public struggle (agon) between the individual and society'.

6. Schopenhauer (2011).

7. See Cavell $(1990,53)$. Conant (2001) echoes this claim.

8. See e.g., Hill $(2003,75)$.

9. See also HL 5, p.84.

10. The following reconstruction of Schopenhauer's metaphysics builds upon that which I put forward in Pearson (2018b).

11. See e.g., Kant $(2007, \S 63, \S 67)$.

12. As Kant (2007, $\$ 66$ [376]) categorically states with respect to organisms.

13. Julian Young $(2006,129-33)$ has persuasively argued that Schopenhauer's understanding of Ideas cannot be equated with that of Plato since Schopenhauer does not reify Ideas.

14. See e.g., PTG, 56.

15. Nietzsche asserts the following in PTG: 'Whatever [the Greeks] learned they wanted to live through, immediately' (31).

16. That ostracism functions as a fall-back moderating mechanism has been observed by Siemens 2001b, 521).

17. Other commentators have also argued that Nietzsche holds an essentialist conception of the self in UM. See Miner (2011, 339ff.).

18. See KSA 7:30[9], 734: 'Harmony is present when everything is related to a middle point, a cardinal force, not when numerous weak forces simultaneously play with one another.'

19. Although it is my contention that Nietzsche presents self-organisation as a conscious process in $\mathrm{UM}$, this is a position that he explicitly rejects in later texts. See e.g., EH 9. Some, such as Gemes (2009), read WB 2 as foreshadowing Nietzsche's position in EH insofar as Nietzsche attributes Wagner's organisation to the fact that his 'ruling passion [became] aware of itself', as opposed to any conscious effort on Wagner's part (47). However, I would respond that elsewhere in WB, Nietzsche makes it clear that he deems Wagner's vibrant holism to be a product of his own conscious labour (see e.g., WB 9, p.244, cited above).

20. For an example of this, see Nietzsche's characterisation of Wagner and Wagner's music in WB 9 (p. 242-3).

21. For a more recent defence of this position, see Hurka (2007, 9-31 [see esp. 17-22]).

22. See also KSA 7:30[8], 733.

23. This point is made by Rowthorn $(2017,109-10)$.

24. Andrew Huddleston draws the same conclusion (2014, 135-60 [fn.3]).

25. Jeffrey Church (2015) offers an interpretation of UM that has points of convergence and divergence with my own. Church argues (in a manner 
that harmonises with my reading) that the 'consecration to culture' that Nietzsche is promoting in UM (SE 6, p.163) is figured as a voluntary affair. However, and this is where his reading departs from my own, he does not view Nietzsche as persuading (i.e., pressuring or manipulating) his readers into making this voluntary sacrifice: 'Rather than coercing individuals, Nietzsche draws on the power of shame that excellent individuals can arouse in the majority' (257). By this Church means that it is by evoking the shame of his readers as they compare themselves to higher individuals such as Schopenhauer that Nietzsche stimulates individuals to consecrate themselves to culture. While this analysis of shame is illuminating and pertinent to our current study, I would ultimately read this act of shaming as a form of psychological coercion.

26. Nietzsche refers to this as the 'refuge of culture' (KSA 7:30[7], 733).

27. As Lemm (2007) suggests. See n.4 above.

28. We should note that the idea that social struggle is ideally perpetual for Nietzsche is not denied by his agonistic readers (though they construe this conflict in terms that are quite different from those found in UM). For example, within his political reading of Nietzsche's agonism, David Owen $(2002,129)$ submits that the ideal Nietzschean citizen 'acknowledges both the openness of the terms of our political association to contestation and the demand that we submit ourselves to the rule of law even as we seek to contest democratically particular laws.'

\section{Disclosure statement}

No potential conflict of interest was reported by the author.

\section{Notes on contributor}

James S. Pearson is a Lecturer in Philosophy at Leiden University (NL). Aside from publishing numerous articles on Nietzsche, he has written on a range of other German-language thinkers, such as Freud, Wittgenstein and Hegel. Thematically speaking, his work focusses on the nature and value of disagreement within the philosophy of language, political philosophy and metaphysics.

\section{ORCID}

James S. Pearson (D) http://orcid.org/0000-0002-6871-3141

\section{References}

Acampora, C. D. 2006. "Naturalism and Nietzsche's Moral Psychology." In A Companion to Nietzsche, edited by K. Ansell-Pearson, 314-334. London: Blackwell. Acampora, C. D. 2013. Contesting Nietzsche. Chicago: University of Chicago Press.

Cavell, S. 1990. Conditions Handsome and Unhandsome: The Constitution of Emersonian Perfectionism. Chicago: University of Chicago Press. 
Church, J. 2015. "Nietzsche's Early Perfectionism: A Cultural Reading of 'The Greek State'." The Journal of Nietzsche Studies 46 (2): 248-260. doi:10.5325/jnietstud.46.2.0248.

Conant, J. 2001. "Nietzsche's Perfectionism: A Reading of Schopenhauer as Educator." In Nietzsche's Postmoralism, edited by R. Schacht, 181-256. Cambridge: Cambridge University Press.

Emerson, R. W. 1870. "The Transcendentalist." In Vol. 1 Of the Prose Works of Ralph Waldo Emerson, 177-194. Boston: Fields, Osgood.

Gemes, K. 2009. "Freud and Nietzsche on Sublimation." The Journal of Nietzsche Studies 38 (1): 38-59.

Hill, K. 2003. Nietzsche's Critiques: The Kantian Foundations of His Thought. Oxford: Oxford University Press.

Huddleston, A. 2014. "'Consecration to Culture': Nietzsche on Slavery and Human Dignity." Journal of the History of Philosophy 52 (1): 135-160. doi:10.1353/ hph.2014.0020.

Hurka, T. 2007. "Nietzsche: Perfectionist." In Nietzsche and Morality, edited by B. Leiter and N. Sinhababu, 9-31. Oxford: Oxford University Press.

Kant, E. 2007. Critique of Judgement. Edited by J. C. Meredith and translated by N. Walker. Oxford: Oxford University Press.

Lemm, V. 2007. "Is Nietzsche a Perfectionist? Rawls, Cavell, and the Politics of Culture in Nietzsche's 'Schopenhauer as Educator'." The Journal of Nietzsche Studies 34 (1): 5-27. doi:10.1353/nie.2007.0019.

Lemm, V. 2013. "Nietzsche, Einverleibung and the Politics of Immunity." International Journal of Philosophical Studies 21: 3-19. doi:10.1080/09672559.2012.746271.

Miner, R. 2011. "Nietzsche's Fourfold Conception of the Self." Inquiry: An Interdisciplinary Journal of Philosophy 54 (4): 337-360. doi:10.1080/ $0020174 X .2011 .592337$.

Nietzsche, F. 1988. Kritische Studienausgabe. 15 Vols, edited by G. Colli and M. Montinari. Berlin: Walter de Gruyter.

Nietzsche, F. 1997a. "David Strauss, the Confessor and the Writer." In Untimely Meditations, edited by D. Breazeale and R. J. Hollingdale, 1-56. Cambridge: Cambridge University Press.

Nietzsche, F. 1997b. "On the Uses and Disadvantages of History for Life." In Untimely Meditations, edited by D. Breazeale and R. J. Hollingdale, 57-124. Cambridge: Cambridge University Press.

Nietzsche, F. 1997c. "Richard Wagner in Bayreuth." In Untimely Meditations, edited by D. Breazeale and R. J. Hollingdale, 195-254. Cambridge: Cambridge University Press.

Nietzsche, F. 1997d. "Schopenhauer as Educator." In Untimely Meditations, edited by D. Breazeale and R. J. Hollingdale, 125-194. Cambridge: Cambridge University Press.

Nietzsche, F. 1997e. Untimely Meditations. Edited by D. Breazeale and R. J. Hollingdale, 125-194. Cambridge: Cambridge University Press.

Nietzsche, F. 1998. Philosophy in the Tragic Age of the Greeks. Translated by. M. Cowan Washington, DC: Regnery.

Nietzsche, F. 2006. "Homer's Contest." In The Nietzsche Reader, edited by K. AnsellPearson and D. Large, 95-100. Blackwell: Oxford.

Nietzsche, F. 2007. "Ecce Homo." In The Anti-Christ, Ecce Homo and Other Writings, edited by A. Ridley and J. Norman, 69-152. Cambridge: Cambridge University Press. 
Nietzsche, F. 2009. Writings from the Early Notebooks. Edited by R. Geuss and A. Nehamas, and translated by L. Löb. Cambridge: Cambridge University Press.

Owen, D. 2002. "Equality, Democracy, and Self-Respect: Reflections on Nietzsche's Agonal Perfectionism." The Journal of Nietzsche Studies 24 (1): 113-131. doi:10.1353/nie.2002.0014.

Pearson, J. 2018a. "Nietzsche on the Sources of Agonal Moderation." The Journal of Nietzsche Studies 49 (1): 102-129.

Pearson, J. 2018b. "Unity in Strife: Nietzsche, Schopenhauer and Heraclitus." In Conflict and Contest in Nietzsche's Philosophy, edited by J. Pearson and $\mathrm{H}$. Siemens, 44-69. London: Bloomsbury.

Rawls, J. 1971. A Theory of Justice. Cambridge, MA: Harvard University Press.

Richardson, J. 1996. Nietzsche's System. Oxford: Oxford University Press.

Rowthorn, D. 2017. "Nietzsche's Cultural Elitism." Canadian Journal of Philosophy 47 (1): 97-115. doi:10.1080/00455091.2016.1233381.

Schopenhauer, A. 2011. The World as Will and Representation. Vol. 1. Translated and edited by. J. Norman, A. Welchman, and C. Janaway. Cambridge: Cambridge University Press.

Siemens, H. 2001a. "Agonal Configurations in the Unzeitgemäße Betrachtungen." Nietzsche-Studien 30: 80-106. doi:10.1515/9783110172409.80.

Siemens, H. 2001b. "Nietzsche's Political Philosophy: A Review of Recent Literature." Nietzsche-Studien 30: 509-526. doi:10.1515/9783110172409.509.

Tuncel, Y. 2013. Agon in Nietzsche. Milwaukee: Marquette University Press.

Young, J. 2006. Schopenhauer. London: Routledge. 